\title{
Home and Dwelling: Re-Examining Race and Identity Through Octavia Butler's Kindred and Paul Beatty's The Sellout
}

Scott Astrada

Journal of French and Francophone Philosophy - Revue de la philosophie française et de langue française, Vol XXV, No 1 (2017) 105-120.

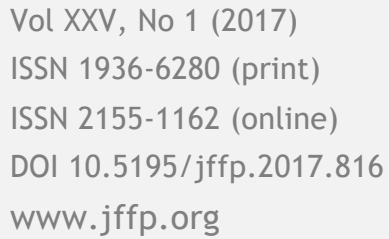

\section{(oc) EY-NO-ND}

This work is licensed under a Creative Commons Attribution-Noncommercial-No Derivative Works 3.0 United States License.

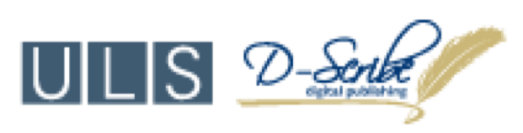

This journal is operated by the University Library System of the University of Pittsburgh as part of its D-Scribe Digital Publishing Program, and is co-sponsored by the University of Pittsburgh Press 


\title{
Home and Dwelling
}

\section{Re-Examining Race and Identity Through Octavia Butler's Kindred and Paul Beatty's The Sellout}

\author{
Scott Astrada
}

The question of how to exist, to dwell, within one's physical and psychological home has become an urgent one in an increasingly globalized world. Yet the answer to this question has never been more fleeting, yet extremely urgent. Lacking universal political or sociological narratives in what can be oversimplified as a post-colonial or post-modern milieu, reformulating the question of how one dwells within one's home has become both relevant and essential. This essay explores a return to the question of how one dwells, not in pursuit of a theoretical harmonizing answer, but to reevaluate how the question is generally framed-a return to the foundation of how one exists, or more precisely, how a one exists. Through Martin Heidegger's essay on dwelling and Michel Foucault's understanding of history as power, my reading of two works of modern fiction captures the struggles of subjects attempting to define their place in the world. Examining how the protagonists of Octavia Butler's Kindred and Paul Beatty's The Sellout dwell within their homes provides much insight into how race, identity, and history impact dwelling in a global age.

\section{Heidegger's Dwelling: The Emergence of a Historical Subject}

The starting point of this return is Martin Heidegger's essay "Building Dwelling Thinking." ${ }^{\prime}$ Here, Heidegger is concerned with the concept of locations, spaces, and how they serve as a clearing for the emergence of Being. These spaces actively shape what occupies them, and influence what is connected by the circumference of their core emptiness, thereby creating a manifestation of Being that is arbitrary yet full of being. We see this in Heidegger's example of a bridge that crosses a stream: "[i]t does not just connect banks that are already there. The banks emerge as banks only as the bridge crosses the stream.... It brings stream and bank and land into each

Journal of French and Francophone Philosophy | Revue de la philosophie française et de langue française Vol XXV, No 1 (2017) | www.jffp.org | DOI 10.5195/jffp.2017.816 
other's neighborhood." ${ }^{2}$ It is in this formulation of essence, fundamentally informed by locations and spaces, that the individual emerges within history. The various structural components of identity (i.e. culture, race, gender, geography) come into "each other's neighborhood," and from an arbitrary confluence of structures emerges a historical subject full to the brim of being/essence. Here is where the space creates a clearing that "makes room for the fourfold ${ }^{3}$ in a double sense. The location admits the fourfold, and it instills the fourfold. The two-making room in the sense of admitting and in the sense of instilling-belong together. As a double space-making, the location is a shelter for the fourfold, by the same token, a house" ${ }^{\prime \prime}$ This is how the space of the subject emerges ostensibly as a singular location, deriving an essence from the praxis of self-consciousness, and also as a compilation of intersections. Yet these arbitrary structures are infused with essence, because the subject breathes life into them and experiences the collective as a unit, as a home not as a mere intersectionality of identity. However, this location, as the emergence of the subject, is not a homogenous and permissive foundation into which culture is simply absorbed. Butler's Kindred and Beatty's The Sell-out recount how this space of self-consciousness is compromised, in one way or another, by the uninvited Other within one's dwelling-a blurring of the line of self and other in the very dwelling space of the subject. This is distinct from the act of locating an additional or confrontational layer of alienation by an imposed colonial ideology on a subject who has been integrated, subjugated, and exists on the periphery of their own identities.

These spaces of identity, which both admit and instill the foundational notions of self-consciousness, exist contemporaneously (as a web expanding around the social and political) and historically (as the culmination of the historical subject). These two axes, the lateral identity (as the locus of the intersection of socio-historical systems) and the historical identity (as the locus of inherited history on the individual level) are inextricably intertwined, working within and upon each other, but creating two distinct lived experiences of existence for the subject. The subject as consciousness both interprets its place in the world, and is simultaneously defined by it.

Here we can equate the individual with location per Heidegger, one that admits and instills the colonial/Other into being through one's dwelling (identity). As postcolonial notions of race and history gain ground in a variety of discourses, there is an evolving recognition of how subjects become aware of their own history, both passively and subjectively, as they navigate a world moving rapidly toward a globalized history and political economy yet still powered by colonial notions of race, power, and politics. Thus my reading of Butler's and Beatty's novels will examine their respective protagonists in terms of their lateral and historical identity (as defined above), and how in both texts the subject (or the space of the subject) interprets, and is defined by its place of dwelling.

Journal of French and Francophone Philosophy | Revue de la philosophie française et de langue française Vol XXV, No 1 (2017) | http://www.jffp.org | DOI 10.5195/jffp.2017.816 


\section{Historical Identity \& Kindred: History’s Unrelenting Grasp}

The relationship of a subject to their history is the very question of Heidegger's notion of location. How one creates the world is not simply how one views it, for how one views the world relies in turn upon historical context that determines structures of perception (both physical and conceptual). Yet that does not resolve the question. There remains a vulnerability of the Other (the ordering of power relationships), a reliance upon the other (the subject) to manifest its existence via action in the world. Without this action, without this manifestation through the subject and within the space of the subject, the Other remains condemned to idealismnothing more than a collective dream behind a firewall separate from existence. The Other and the other thus engage in a struggle when the subject asserts its progression from, or away from, the definitions and structures imposed by the Other. Put directly, this is the struggle of a subject that rebels against itself (as a manifestation of the Other through itself as a historical subject). While it is commonplace to understand the influence of the past on the present, Octavia Butler's Kindred ${ }^{5}$ conveys the struggle of the Other and the other in a manner that captures the complexity of battling one's own history, and poses the question of how one lives moving forward in history, when so much of one's home is determined by the past.

In Kindred, we can see how the historical space of being, of the individual, is not only influential in configuring the subject's grid of perception, but violently captures and molds the very space of perception. The protagonist, Dana, journeys back and forth from the present (1970s) back in time to the 1800s, experiencing a violent tug-of-war with her white slave holder ancestor Rufus, who somehow has the power to summon her back in time. During her first trip back in time, Dana saved the young Rufus from drowning in a river. She returns shortly after rescuing Rufus when she is staring down the barrel of his father's shotgun as she drags Rufus to the riverbank. After this initial journey destabilizes her sense of home, she no longer feels safe: "[m]aybe I'm just like a victim of robbery or rape or something - a victim who survives, but who doesn't feel safe anymore."。 Here is the first division of her home in both space and time. A divide between her present reality as an African-American woman, married to a white man, living in a world increasingly gathering behind notions of civil rights and equality, and her past, in which she confronts her slave-holding ancestor. Dana's bloodline conflates her past and present in one sweeping motion.

Dana's journey back in time, beyond the obviously disconcerting experience, presages subsequent trips that augment and violently reconfigure her sense of home, and more importantly where she considers home to be. After the first experience, and the fear she expresses of not

Journal of French and Francophone Philosophy | Revue de la philosophie française et de langue française

Vol XXV, No 1 (2017) | http://www.jffp.org | DOI 10.5195/jffp.2017.816 
knowing when it might happen again, her home is cast in a state of flux, only to be resolved at the end of the book with Rufus's death.

What Dana realizes after subsequent trips is that Rufus controls when she travels back in time. Whenever Rufus nears death, he unconsciously pulls Dana back in time to save his life, whether from a fire, a drowning, a vicious fight, or even potential suicide. Dana always travels back to the time and place where Rufus needs her to save his life. Dana was at his mercy: "[t]he boy [Rufus] drew me to him somehow when he got himself into more trouble than he could handle [...] He apparently didn't even know he was doing it." $>$ The fact that Rufus was unaware of his power, arguably until the very end, creates a power dynamic more nuanced than that of straightforward master/slave relation. This becomes especially apparent when Dana realizes that Rufus was Dana's ancestor, and that if something were to happen to him, she might cease to exist in her own time: "[w] as that why I was here? Not only to insure the survival of one accident-prone small boy, but to insure my family's survival, my own birth." ${ }_{s}$ The original division of Dana's home now assumes a tinge of blackmail, a forced complicity to keep the Other alive. There is an amalgamation of tyranny, exploitation and complicity at the heart of Dana's identity as she saves Rufus again and again. Here is where the Other is at its most powerful in its struggle to exist through the other. A subject, in this case Dana, must save the Other-Rufus and the slave holding society that enables his positionnot out of agreement or empathy, but of necessity-without the Other I might not exist. The tie that binds Dana to Rufus is preclusive, and what saves Dana is her fear of death which sends her back to her own time; "Rufus's fear of death calls me to him, and my own fear of death sends me home.". Here Rufus's future as an individual relies upon Dana, and Dana is ostensibly reliant upon Rufus for her future existence as a historical subject. It is only at the end of the novel when Dana kills Rufus because he tries to rape her (refusing the Other), that Dana's future (and past) is free. But her freedom comes at a cost. Dana is jettisoned back to her present day after killing Rufus, but loses her arm after it is melded into one of the walls of her home upon her return. Dana in essence loses part of her body (her arm, one of the primary ways one manifests the Other in the world via pen or sword, or action) to her home, after expelling the Other from it.

Yet before the finality of Rufus's death, Dana experiences contradictory feelings for him, similarly to how the slaves of his own time viewed him:

[The other slaves] made gross jokes about him [Rufus] behind his back. Strangely, they seemed to like him, hold him in contempt, and fear him all at the same time. This confused me because I felt just about the same mixture of emotions for him myself.... But then, slavery of any kind fostered strange relationships. Only the overseer drew simple, unconflicted emotions of hatred and fear

Journal of French and Francophone Philosophy | Revue de la philosophie française et de langue française Vol XXV, No 1 (2017) | http://www.jffp.org | DOI 10.5195/jffp.2017.816 
when he appeared briefly. But then, it was part of the overseer's job to be hated and feared while the master kept his hands clean..$^{10}$

This is the ambiguous origin of the subject, the contradictory nature of Dana and Rufus's relationship: the occupation of contradictory feelings within the same space, destined to be together, to interact, but always as separate and competing entities that could never absorb the other. And it is this mix of tyranny, complicity, and blackmail that drives the conflict. The overseer is the role of unambiguous and manifest evil, which allows the master, the Other, to seem removed from unambiguous tyranny. However, the overseer is never at the heart of the Other. It is the overseer's role to allow the Other to reside in one's home as the primordial ancestor (here defined as Rufus) and as a tyrant-it is this duality that defines the Other. Yet this duality exists only from transference of pure tyranny away from the Other and into the 'overseer' (the role that absorbs uncomplicated hatred), thus allowing the Other to appear ambiguous. This ambiguity grows through each of Dana's trips back in time; as Rufus grows older she nurtures and supports his journey toward becoming a plantation owner.

Another central struggle arises between the past and Dana's white husband. When he accidently travels back in time with her, and gets stranded there for years, Dana recognizes the danger of the past infringing upon the present. Or more precisely, that the norms of the past are not simply relics, fossils in a museum that we can gaze upon as markers of progress, but lay dormant in our present, and it is the context of the present that allows them to manifest or remain latent in the shadows of consciousness. More than just his physical safety, Dana worries about "another" kind of danger:

A place like this [the past] would endanger him in a way I didn't want to talk to him about. If he was stranded here for years, some part of this place would rub off on him. No large part, I knew, But if he survived here, it would be because he managed to tolerate the life here. He wouldn't have to take part in it, but he would have to keep quiet about it.... The place, the time would either kill him outright, or mark him somehow."

Here is the locus of her husband's struggle with the past infringing upon the present, the resistance to complicity. As a white male in a slaveholding society, a different dynamic defines his struggle with the Other: the danger of complicity by inaction-of passive manifestation. This is a struggle between passivity and action, as opposed to Dana who cannot simply remain inert-for her there is either invasion or repulsion. Here we see how structural positions define the struggle of various subjects in their individual revolts against the Other.

Dana's sense of home is further divided and compromised when the past starts to feel like home. This uncanny sense of dwelling in the past

Journal of French and Francophone Philosophy | Revue de la philosophie française et de langue française Vol XXV, No 1 (2017) | http://www.jffp.org | DOI 10.5195/jffp.2017.816 
develops as Dana defines herself and her husband as actors, which in turn allows them to adjust to their new present: "[t]hat disturbed me too when I thought about it. How easily we seemed to acclimatize. Not that I wanted us to have trouble, but it seemed as though we should have had a harder time adjusting to this particular segment of history-adjusting to our places in the household of a slaveholder." ${ }_{12}$ She resolves this by concluding that they are "actors":

I began to realize why Kevin and I had fitted so easily into this time. We weren't really in. We were observers watching a show. We were watching history happen around us. And we were actors. While we waited to go home, we humored the people around us pretending to be like them. But we were poor actors. We never really got into our roles. We never forgot we were acting. This was something I tried to explain to Kevin on the day the children broke through my act. It suddenly became very important that he understand. ${ }^{13}$

The passage's conclusion-that that she and her husband were "actors" — as the reason they were able to acclimatize to the norms of slave holding society is quickly undermined by its last sentence. Dana desperately needs to have her husband understand that they are "actors," almost as if excusing her husband's comfort with her own rationalization. But this illusion is shattered when she witnesses the spectacle of slave children 'playing' slave, as if they were auctioning each other off to frugal buyers. Her husband informs her that the children also 'play' at field work: "[e]ven the games they play are preparing them for their future - and the future will come whether they understand it or not." ${ }_{14}$ Here is where Dana confronts the social objectivity of a manifest history that demolishes self-images and the actors' masks, and it is not in the subject's control to determine when one can end the game, or even whether one is acting or being authentic when manifesting the Other. Dana, unlike the other slaves, can escape the game of being a slave when she feels her life is threatened; but she sacrifices the division between then and now, between the play and the audience, as she no longer has a stable subject position-a "here" - from which to participate in history. This is the cost of living in a now at odds with the past, of waging war with the Other. To wage war with one's social destiny is to blur the lines between the present and the past-to recognize the historical subjectivity of one's now. As a result Dana, without a present, has no basis for action, as she realizes: “...I can't maintain the distance. I am drawn all the way into eighteen nineteen, and I don't know what to do. I ought to be doing something though. I know that." ${ }_{15}$ Toward the end of the novel, after her husband spent years in the past, and she has made numerous trips back in time, her home begins to slip away: "[t]he time, the year was right [1970s], but the house just wasn't familiar enough. I felt as though I were losing my place here in my own time. Rufus's time was a sharper, stronger reality." ${ }_{16}$

Journal of French and Francophone Philosophy | Revue de la philosophie française et de langue française Vol XXV, No 1 (2017) | http://www.jffp.org | DOI 10.5195/jffp.2017.816 
Dana also begins to feel the past in the presence of her husband: "[t]he expression on his face was like something I'd seen, something I was used to seeing on Tom Weylin [Rufus's father]. Something closed and ugly." ${ }^{\prime 口}$ Dana is experiencing the blurring of the lines between past and present, and the disappearance in turn of the singularity and location of her home.

The consequences of Dana's safeguarding of Rufus are not lost on her: "[s]omeday Rufus would own the plantation. Someday, he would be a slaveholder, responsible in his own right for what happened to the people who lived in those half-hidden cabins. The boy was literally growing up as I watched-growing up because I watched and because I helped to keep him safe. I was the worst possible guardian for him-a black to watch over him in a society that considered blacks subhuman, a woman to watch over him in a society that considered women perennial children." ${ }_{18}$ Dana resolves this conflict as a battle she is waging on Rufus's territory, hoping her presence and actions will disrupt the Other from fully manifesting through Rufus when he grows up, planting ideas in his head to change his future. She shares this with her husband who responds that "his environment will be influencing him every day you're gone. And from what I've heard, it's common in this time for the master's children to be on nearly equal terms with the slaves. But maturity is supposed to put both in their 'places'.... Hell you're gambling against history." "Dana is battling the Other on its own terms, from within her lost home, armed only with dreams of future equality and the revelation to Rufus that slavery will be abolished in the future. Yet Rufus seems to validate Dana's husband, when he expresses his indifference, or acceptance of the Other, as Rufus has no desire to battle the world around him or to challenge it: "[b]ut I read as good as Daddy does already. Why should I have to do more than that?" ${ }_{20}$ And Rufus is completely unconcerned with the future, as evidenced by his remarks about an abolitionist book (written 100 years after slavery) that Dana shares with him: "...why the hell are they still complaining about it?" ${ }_{21}$ Here lies the locus of all three characters' struggles: the vulnerability of the present to the past (and future), and the refusal to risk losing the location of self, by venturing into dreams of the future or the grim realities of the past. This refusal imprisons Rufus, and ultimately leads to his death.

After Dana finally kills Rufus, she is not "unborn," so to speak, but permanently scarred from confronting her past and expelling the Other. She remains, even after murdering Rufus, but the necessary consequence is that she is no longer whole (even if this uniformity was a farce to begin with). Yet she as a subject persists, and transcends the Other that used being as the ultimate threat to justify its existence. Historical identity at its center is the struggle with a subject locked in a battle with its history. Not from the external systemic locus of the Other, but as a subject that is the space of the Other manifest.

Journal of French and Francophone Philosophy | Revue de la philosophie française et de langue française Vol XXV, No 1 (2017) | http://www.jffp.org | DOI 10.5195/jffp.2017.816 


\section{Defining Lateral Identity: Space and Location}

The characteristics of Heidegger's locations can be inscribed within various social eras, by an understanding of how the historical spaces within which individuals dwell uniquely create consciousness. Foucault's lectures on biopolitcs provide a prime starting point for understanding how these spaces admit and instill the other, in terms of locating that which exists only in a relation to a social network and in contextual relations between and within power structures:

[The] question here is the same as the question I addressed with regard to madness, disease, delinquency, and sexuality. In all these cases, it was not a question of showing how these objects were for a long time hidden before finally being discovered, not of showing how all these objects are only wicked illusions or ideological products to be dispelled in the [light] of reason finally having reached its zenith. It was matter of showing by what conjunctions a whole set of practices- from the moment they become coordinated with a regime of truth - was able to make what does not exist (madness, disease, delinquency, sexuality, etcetera), nonetheless become something, something however, that continues not to exist. That is to say, what I would like to show is...how a particular regime of truth, and therefore not an error, makes something that does not exist able to become something. It is not an illusion since it is precisely a set of practices, real practices, which establishes it and thus imperiously makes it out in reality.... what I am talking about now, is to show how the coupling of a set of practices and a regime of truth form an apparatus (dispositif) of knowledge-power that effectively marks out in reality that which does not exist and legitimately submits it to the division between true and false.2

A key aspect of Foucault's truth regime is that the concepts that emerge from the interrelation of various discourses are not spaces where ontic or platonic truth resides. Even in exclusion, there is no metaphysical essence beyond the relationship between the excluding power structure and the marginalized position; that "something" that is brought into being, but continues to not exist in a metaphysical sense. This speaks directly to the reality of one's identity in a post-colonial context where the discernable figurehead of subjugation has ostensibly vanished (in terms of an empire), but remains in the machinery of the social. Without a definitive counterpoint, the resulting flux of the power dynamic creates this space that is at once determined by, and determines, these structures as they manifested in a subject's actions and thoughts as they enter the social fabric of empirical policy and institutional movement. The space of identity is this dual movement of manifesting the other (the colonial other in terms of the excluded subject) through the individual's existential subjectivity, and concurrently, the preempting of the subject's freedom of perception by their own history. This

Journal of French and Francophone Philosophy | Revue de la philosophie française et de langue française Vol XXV, No 1 (2017) | http://www.jffp.org | DOI 10.5195/jffp.2017.816 
dual movement can be explored and traced through an analysis of both the space of the self and the space of history, to arrive at a more precise understanding of identity and dwelling in the contemporary world. As opposed to the historical struggle as outlined in Kindred, the Lateral Identity of the subject, one not held hostage by the past, but persisting in the aftermath of the struggle, emerges in Paul Beatty's novel The Sellout. ${ }^{23}$ Here, the historical notion of Foucault's power regime is illuminating, as the narrator attempts to define what he $i s$ as an African-American male, outside of the Other and outside of the promises and dreams of history (not history itself per se, as one can never "escape" history). Yet he dwells within the structures of the Other, in law, society, and identity politics.

\section{The Sellout: "So what exactly is our thing?"}

Paul Beatty's novel The Sellout follows an African-American narrator who is removed from Kindred's violent battle between present and past. The novel recounts its narrator's rethinking-and seemingly discarding-notions of metaphysical essence surrounding historical identity, through his efforts to reinstate segregation and slavery in his hometown. At the start of the novel the narrator stands before the Supreme Court of the United States regarding case number 09-2606, Me v. the United States of America. The case is highly controversial as it accuses the narrator (named $\mathrm{Me}$ ) of reinstating slavery. The narrator makes his case directly to readers, as if he were addressing the Justices, starting with the novel's opening sentence: "[ $\mathrm{t}]$ his may be hard to believe, coming from a black man, but I've never stolen anything." ${ }_{24}$ Such a statement assumes that the reader is white. Yet, the narrator quickly reconfigures his outsider status in relation to all races, far from the Other's ability to solidify identity and place: the ethos of an identity.

The search for the ethos of his identity, a uniting a priori definition of race, was a priority since Me's childhood, as he explains: "[g]rowing up, I used to think all of black America's problems could be solved if we only had a motto." ${ }_{25}$ The redemption in unity, in uniformity, as a result not of exclusion but of ontology, is the default concept of social and cultural advancement, one that transcends economies, histories, and cultures, that serves as a benchmark for measuring progress. The narrator invests in this belief, stating that "[e]very race has a motto," ${ }_{26}$ but he quickly grows frustrated in his attempts to find a motto that can encompass everything, one that fits neatly into an either/or definition. Yet at the opening of the book, Me stands before the law, where one has to be either/or, one or the other: "[d]umfounded, I stood before the court, trying to figure out if there was a state of being between 'guilty' and 'innocent'. Why are those my only alternatives? I thought. Why couldn't I be 'neither' or 'both'?" ${ }_{27}$ Indeed, standing accused of reinstituting slavery, he struggles "to be on trial for my life, and for the first time ever not feel guilty.... I understand now that the

Journal of French and Francophone Philosophy | Revue de la philosophie française et de langue française Vol XXV, No 1 (2017) | http://www.jffp.org | DOI 10.5195/jffp.2017.816 
only time black people don't feel guilty is when we've actually done something wrong, because that relieves us of the cognitive dissonance of being black and innocent...." ${ }_{28}$ As Me faces the Justices (one of whom is African-American), and the censure of the African-Americans in attendance, he tries to cultivate his historical identity, as someone who should regret his crime: "[u]ncomfortable with being so comfortable, I make one last attempt to be at one with my people." ${ }^{29}$ He tries to focus on the civil rights movement, the violence it imposed, Selma, and other major historical milestones in African-American history, but can only envision the participants in these events as zombies, with "the head zombie" looking "exhausted from being raised from the dead every time someone wants to make a point about what black people should and shouldn't do, can and cannot have." ${ }^{\prime \prime}$ Here the disconnect between the narrator and history embodies the lateral notion of the space of the subject, one who is not unaware of history, but feels fundamentally unattached from it, from a history that lacks ethos-a zombie-like apparition where the arbitrariness of the Other stands front and center. The struggle here is antipodal to the one in Kindred: It is a fight for meaning, rather than a flight from (tyrannical) meaning.

Me continues his case with an explanation of his childhood, and how he learned to be black. He recounts how he was raised by a father (the sole practitioner of "liberation psychology") who utilized techniques to socialize and imprint a Pavlovian sense of black identity on him. His father would put "toy police cars, cold cans of Pabst Blue Ribbon, Richard Nixon campaign buttons, and a copy of The Economist in my bassinet [...] I learned to be afraid of the presented stimuli because they were accompanied by him taking out the family .38 Special and firing several window-rattling rounds into the ceiling, while shouting " $\mathrm{N}^{* * *}$ er, go back to Africa!" ${ }^{31}$ Through similar techniques, the narrator's father inscribes "blackness" into his psyche. ${ }^{32}$ Symbols of identity (blackness) are imprinted solely in a historically lateral sense, as lynch-pins of identity, devoid of the historical culmination of social relationships. What results is not a socialized individual, but rather a detachment and exclusionary basis of identity that the subject cannot grasp. As the (unofficial) neighborhood psychologist, his father's central question was "Who am I? and how may I become myself?" throughout the novel as the narrator's own defining struggle, as he tries to answer this question: "[s]o introspective questions like 'Who am I? And how can I be that person?' didn't pertain to me then, because I already knew the answer. Like the entire town of Dickens, I was my father's child, a product of my environment, and nothing more. [....] Problem is, they both disappeared from my life [...] and suddenly, I had no idea who I was, and no clue how to become myself." ${ }^{34}$ Here is the radical separation of being and self, as it exists outside of its foundational environment. Even with the main signifiers of the Other erased (despite the subject's relationship with them) the subject itself does not disappear, but remains restricted in limbo, without

Journal of French and Francophone Philosophy | Revue de la philosophie française et de langue française Vol XXV, No 1 (2017) | http://www.jffp.org | DOI 10.5195/jffp.2017.816 
a central referent to ground it. As opposed to Kindred, the subject is not disfigured, not rendered incomplete, but rather suspended in mid-air with the loss of the Other. But yet, the converse also makes itself apparent, namely that the entirety of a subject's being cannot be completely encapsulated within its historical environment; although the environment structures the self's perceptual grid, the subject's context is inseparable from the self but does not exhaust it. And the inability to answer the question "Who am I?" in the absence of central referents is the subject's exposure to this marginal "space." However, the subject cannot dwell in this space, as it relies by definition upon manifesting an Other, even its inverse. However, this marginal space resists the postmodern onslaught of the proliferation of labels to define and give voice to it. It is this contradiction that leaves the narrator unfulfilled with by the search for a motto, but then cannot answer the question "Who am I?" (again, an example of the failure of an either/or categorization required before the law).

After the death of his father and the disappearance of the city of Dickens, the narrator goes to extreme measures to put his city back on the map. This mission ultimately leads to Dickens resident Hominy Jenkins, the last Little Rascal alive and the only African-American among the Rascals. The elderly Hominy was the product of a stereotypical and racist media industry as a Little Rascal, often portrayed in demeaning and humiliating racist situations. However, Hominy embraced that identity with such enthusiasm, both as a child and as a resident of Dickens, that he was generally regarded as "a mark of shame on the African-American legacy, something to be eradicated, stricken from the racial record, like the hambone, Amos ' $n$ ' Andy, Dave Chappelle's meltdown, and people who say "Valentime's Day." ${ }^{35}$ In fact, Hominy took the city's disappearance so hard he tried to commit suicide, because he felt so irrelevant and fans no longer visited. When narrator Me saved his life by foiling a suicide attempt, Hominy pledges himself as a slave to the narrator. Hominy tells the narrator, "sometimes we just have to accept who we are and act accordingly. I'm a slave. That's who I am. It's the role I was born to play. A slave who just also happens to be an actor." ${ }_{36} \mathrm{Me}$ is, in a sense, stuck with Hominy, after trying repeatedly to rid himself of Hominy's 'service': "I tried to "free" Hominy countless times. Simply telling him he was free had no effect," ${ }^{\prime}{ }$ as Hominy would simply use his freedom to choose slavery. Here Hominy, unable to resist the Other, or exist outside if it, must, by any means, have an answer to the question "Who am I?"

With Hominy under his proprietorship, the narrator goes about reestablishing his city. In the most forthright way, he starts to draw a line of white spray-paint around the city's former border. The narrator also is assisted by the other residents: "[s]ometimes, after retiring for the day, I'd return the next morning, only to find that someone else had taken up where I'd left off. Extended my line with a line of their own, often in a different

Journal of French and Francophone Philosophy | Revue de la philosophie française et de langue française Vol XXV, No 1 (2017) | http://www.jffp.org | DOI 10.5195/jffp.2017.816 
color. Sometimes the line wouldn't be a line at all but drops of blood, or an uninterrupted string graffiti signing off on my efforts...." ${ }^{38}$ The arbitrary nature of the line was not lost on any of the residents, including the narrator, but once the line was drawn, the residents immediately "saw" the city manifest and with "[p]uzzled looks on their faces from asking themselves why they felt so strongly about Dickens side of the line as opposed to the other side.... When it was just a line." ${ }^{39}$

With Hominy as his slave, and the city lines literally redrawn, Me decides to segregate Dickens as a way to save it from disappearing into irrelevance. Central to this endeavor is that the city is primarily occupied by racial and ethnic minorities, primarily African-Americans and Chicanos. De facto segregation already existed in Dickens, economically and racially, but much like the line the narrator draws around the city, by posting a "white's only" sign on the bus, segregation becomes manifest and emerges from a web of Foucauldean relationships not as an ontic reveal, but as a manifest reality relying on legal and perceptive power structures. The city's racial demographics presented an obstacle to $\mathrm{Me}^{\prime} \mathrm{s}$ mission of imposing segregation in all facets of daily life in Dickens, when he had to ask himself "[h]ow do you racially segregate an already racially segregated school?" The ultimate irony in Me's posting of the "white's only" sign is that it became central to the new Dickens's experience: "[It's] the signs. People grouse at first, but the racism takes them back. Makes them humble. Makes them realize how far we've come, and, more important, how far we have to go. On that bus it's like the specter of segregation has brought Dickens together." ${ }^{11}$ Similar to the city lines marked with white spray paint, the realities of pre- and post-segregation Dickens (as defined by the "white's only" sign) are by objective standards the same (if defined by poverty, demographic segregation, and disenfranchisement). However, outlining segregation as a thing of the past defines both the loss of progress, by realizing that nothing has empirically changed, and the feeling that so much progress has occurred. This again is a sentiment that does not fit into an either/or categorization, as the narrator alludes in his opening statement regarding the not guilty/guilty verdict.

The notion of race, primarily whiteness, is of prime significance in a community essentially already segregated along demographic lines. The narrator expands the notion of whiteness beyond mere biology: "[Even] the ones who are biologically white aren't white white. Laguna Beach volleyball white. Bel Air white... Three first names white. Valet parking white. Brag about your Native American, Argentinian, Portuguese ancestry white...." Here again we see the lateral definition of the Other in Foucault's notion of history. The narrator expands the definition of blackness's own historical and biological determinations: "everyone in Dickens, regardless of race, was black and you determined someone's degree of blackness not by skin color or hair texture but by whether they said 'For all intents and purposes' or 'For

Journal of French and Francophone Philosophy | Revue de la philosophie française et de langue française Vol XXV, No 1 (2017) | http://www.jffp.org | DOI 10.5195/jffp.2017.816 
all intensive purposes'." 4 This statement displaces 'black' and 'white' as racial categorizations, instead relying on structural positions of the marginalized and the privileged. It is the ambiguous dual movement of freeing the signifier 'blackness' from a necessary signified of deprivation and disenfranchisement, at the same time ignoring empirical socio-economic realities and the inherited history of African-American social and economic marginalization in the U.S (another history that resists either/or categorization). This is the price the narrator pays for confronting the Other, by refusing to manifest its power regime. Unlike Dana's experience in Kindred, this movement does not result in a loss of unity or disfigurement, but rather a loss of self, of ground-in short, homelessness.

The quest for segregation concludes toward the end of the novel, as the narrator is arrested for owning a slave. Shortly before Me's arrest, Hominy quits slavery, remarking to the narrator that "we'll talk reparations in the morning." " After his arrest Me again stands before the law as the judge states:

[The] irony is not lost on me that we sit here in the courtroom-a female state's attorney general of black and Asian lineage, a black defendant, a black defense counselor, a Latina bailiff, and me, a Vietnamese-American district judge-setting the parameters for what is essentially a judicial argument about the applicability, the efficacy, and the very existence of white supremacy as expressed through our system of law. And while no one in this room would deny the basic premise of 'civil rights', we'd argue forever and a day about what constitutes 'equal treatment under the law' ${ }^{45}$

Here is where the disappearance of the authoritarian figurehead casts the structure it is meant to anchor into disarray. In a diverse, multicultural court of Law, where does the power of the Other reside? In a free society, where does segregation reside when all the data clearly marks the presence of segregation?

Me confronts this question as he listens to his father's comprehensive theory on "Quintessential Blackness." It is a theory based on linear development rather than a metaphysical clearing of black identity. This theory develops through three stages, from a precociousness state toward a "race transcendentalism" culminating in a "collective consciousness that fights oppression and seeks serenity." ${ }_{46}$ This third stage includes such historical figures as Rosa Parks, Harriet Tubman, Sitting Bull, Cesar Chavez, Ichiro Suzuki, and people "who believe in beauty for beauty's sake." final stage also conflates race and structural resistance to oppression into a universal consciousness forged in resistance no longer based on race. In evaluating his father's theory, Me posits his own additional stage:

There should be a Stage IV of black identity - Unmitigated

Blackness. I am not sure what Unmitigated Blackness is, but

Journal of French and Francophone Philosophy | Revue de la philosophie française et de langue française Vol XXV, No 1 (2017) | http://www.jffp.org | DOI 10.5195/jffp.2017.816 
whatever it is, it doesn't sell.... Unmitigated Blackness is simply not giving a fuck.... It's the realization that there are no absolutes, expect when there are. It's the acceptance of contradiction not being a sin and a crime but a human frailty like split ends and libertarianism. Unmitigated Blackness is coming to the realization that as fucked up and meaningless as it all is, sometimes it's the nihilism that makes life worth living. ${ }^{48}$

This passage recognizes the contradictory nature of postcolonial identity ("that there are no absolutes except when there are"): that there is no either/or once the Other is exposed, but instead an ability to detach from identity in the hope that one is free to respond (or not) as an individual, and not as a category. Me does not see the culmination of black identity as his father did, as a transcendentalism based on a reactionary struggle, a self defined in opposition. For the narrator, his final stage would be one of "not giving a fuck." The self breathes life into the historical structures of identity, so it is both historically determined and irrefutably existential. Here is the sin that is "not a crime" as described in the narrator's final stage of identity-abandoning the historical identity of Stage III 'blackness', as his father posited, and resurrecting the subject's reign over the Other. This movement does not forsake the history behind such an identity, but suggests the prioritizing of the individual over the confines of historical identity, while also recognizing the real and very empirical nature of concepts and how they manifest and shape the Other (thus "there are no absolutes, expect when there are"). The narrator captures this idea in his understanding of history: "[ $t$ ]hat's the problem with history, we like to think it's a book-that we can turn the page and move the $f^{* *} k$ on. But history isn't the paper it's printed on. It's memory, and memory is time, emotions, and song. History is the things that stay with you." ${ }^{\circ}$ History is that which remains, its memory stemming from the subject, not from the external locus of what one was (or is) through the Other.

The novel's conclusion portrays the narrator at the local donut shop where his father used to lead meetings with community intellectuals. During an open mike night at the shop a white couple is in attendance. The AfricanAmerican comic stops in the mid-routine and kicks out the whites, not because they are unwelcome but because this is "our thing," an event only for Dickens's African-American community. After the incident Me agrees with the comic's action, but wonders "[s]o what exactly is our thing?" ${ }^{\text {so }}$ He is no closer to answering the question "Who am I?"

Rather than succumb to a fatalistic nihilism, the narrator abandons his search for a motto, and instead formulates his Stage IV of black identityUnmitigated Blackness as the reprioritization of the individual. The individual (the other) who, while historically determined, claims the freedom-the "nihilism" of Stage 4-that opens an emancipating space.beyond the infinite dialogue with the Other (as exemplified by the

Journal of French and Francophone Philosophy | Revue de la philosophie française et de langue française Vol XXV, No 1 (2017) | http://www.jffp.org | DOI 10.5195/jffp.2017.816 
judges' comments at the close of the trial). Here the name of the case, Me v. The United States, makes clear that Me's fight comes from the locus of an individual, not a clearing/space for the Other. This individuality allows one to exist outside oneself (as a historical subject) in a manner of speaking, or, put another way, to be a sellout.

The contractionary nature of identity, in the locus of a subject that shapes the world and is shaped by it, clears a space for accountability in the culturally relativist landscape of a globalized world. Far from a moral directive, the recognition that to act outside oneself, even in annihilation of the subject, can be a radical refusal to manifest the Other, is a fundamental aspect of modern dwelling. This does not preclude the ability to actively represent oneself within a political space. The Other is not a passive idea awaiting to become; it is active, it forces itself through the subject both intellectually, by framing perception, and through the social mechanisms of law and political economy (which at their core are the Other working through subjects). It is thus an Other, a historical tyranny of identity and systemic power, pitted against an other who resists as an active "space" that constitutes the heart of modern dwelling. This struggle against the Other, in a lateral sense in The Sellout, and historically in Kindred, is not fighting for one's home, or expelling the other from it, but of willfully reappropriating the terms that the Other has imposed in the very act of building, and thus of dwelling itself.

${ }^{1}$ Martin Heidegger, Poetry, Language, Thought, trans. Albert Hofstadter (New York: Harper \& Row, 1971).

${ }^{2}$ lbid., 150.

${ }^{3}$ The fourfold for Heidegger is the primal oneness of earth and sky and divinities and mortals. Essentially how individuals dwell on earth-by necessary implication of all four. Ibid., 147.

${ }^{4}$ Ibid., 155-156, emphasis in the original.

${ }^{5}$ Butler, Octavia E., Kindred. Beacon Press: Boston, 2003.

${ }^{6}$ Ibid., 17.

${ }^{7}$ Ibid., 26.

${ }^{8}$ Ibid., 29.

${ }^{9}$ Ibid., 50.

${ }^{10}$ Ibid. , 229

${ }^{11}$ Ibid., 77.

Journal of French and Francophone Philosophy | Revue de la philosophie française et de langue française Vol XXV, No 1 (2017) | http://www.jffp.org | DOI 10.5195/jffp.2017.816 
${ }^{12}$ Ibid., 97.

${ }^{13}$ Ibid., 98, emphasis added.

${ }^{14}$ Ibid., 99.

${ }^{15}$ Ibid., 101.

${ }^{16}$ Ibid., 191

17 Ibid., 194

18 Ibid. , 68.

${ }^{19}$ Ibid., 83.

${ }^{20}$ Ibid. , 87.

${ }^{21}$ Ibid., 140

${ }^{22}$ Michel Foucault, The Birth of Biopolitics: Lectures at the Collége de France 1978-1979, ed. Michel Senellart, trans. Graham Burchell (New York: Picador, 2004), 19.

${ }^{23}$ Paul Beatty, The Sellout. Picador Press: New York, 2015.

${ }^{24}$ Ibid., 3.

${ }^{25}$ Ibid. , 10 .

${ }^{26} \mathrm{Ibid}$

27 Ibid., 15.

${ }^{28}$ lbid., 17-18.

${ }^{29}$ Ibid., 18.

${ }^{30}$ Ibid.

${ }^{31}$ Ibid., 29.

${ }^{32}$ In keeping with Heidegger's lexicon, here we have the other inscribing the Other, within another other.

33 lbid., 39.

${ }^{34}$ Ibid., 40.

35 Ibid., 76.

${ }^{36}$ Ibid., 77.

${ }^{37}$ Ibid., 82.

${ }^{38}$ Ibid., 107.

${ }^{39}$ Ibid., 109.

${ }^{40}$ Ibid., 169.

${ }^{41}$ Ibid., 163

Journal of French and Francophone Philosophy | Revue de la philosophie française et de langue française Vol XXV, No 1 (2017) | http://www.jffp.org | DOI 10.5195/jffp.2017.816 
42 Ibid., 119.

${ }^{43}$ Ibid., 164.

44 Ibid., 283.

${ }^{45}$ Ibid. , 265.

${ }^{46}$ Ibid., 276.

${ }^{47}$ Ibid., 277.

${ }^{48}$ Ibid., 287.

${ }^{49}$ Ibid., 115.

${ }^{50}$ Ibid., 288, emphasis in the original.

Journal of French and Francophone Philosophy | Revue de la philosophie française et de langue française Vol XXV, No 1 (2017) | http://www.jffp.org | DOI 10.5195/jffp.2017.816 